\title{
BLENDED LEARNING: DEFINITION, MODELS, IMPLICATIONS FOR HIGHER EDUCATION
}

\author{
A. Bryan,braiana@susu.ru, \\ K.N.Volchenkova,volchenkovakn@susu.ru \\ South Ural State University, Chelyabinsk, Russian Federation
}

\begin{abstract}
The Project 5-100 initiated by the Ministry of Education of Russian Federation is aimed at the internationalization of leading Russian Universities at global education market. In 2015 South Ural State University (SUSU, Chelyabinsk) became part of the Project 5-100, which along with great opportunities posed a number of targets to be achieved to prove the efficiency of changes to be introduced into the education process. One of the projects in SUSU's Road Map is aimed to introduce an innovative system of English language training for bachelor students, which is impossible without the usage of new educational technologies. One of the technologies considered an efficient one is that of blended learning. The article analyzes the concept of blended learning and its didactic possibilities to make an effective transition from a traditional learning model to an integrated one feasible, with electronic environments and resources being widely used. The authors give a critical overview of the existing blended learning models. They also consider the ways blended learning can be adopted for the Russian higher education system, with the focus on the "foreign language" training. The results can be used to develop the models of blended learning courses for higher education.
\end{abstract}

Keywords: Project 5-100, technology, blended learning, model, integration, language learning.

\section{Introduction}

The aim of this paper is to give an introductory overview of 'blended learning', first by investigating the meaning of the term, then secondly by looking at different models, together with some suggested ways of classifying them. Finally, the implications of these models for practitioners are examined, by considering the rationales for adopting blended learning and the challenges involved in its implementation.

The origins of blended learning pre-date the advent of digital technology. Its genealogy lies in distance learning through correspondence courses. In Canada, for example, the children of lighthouse keepers were among those educated thanks to a 1919 scheme [1]. The goal of bridging distance remains a possible motive for using blended learning. The rise of personal computing in the eighties and the advent of the worldwide web in the nineties encouraged the development of new models of the learning process at different levels of education. In higher education, one such new model was Diane Laurillard's 'conversational' approach, which regards learning as an iterative dialogue between student and teacher. This model remains an influence on current debates about blended learning [2]. Digital technology also began to be introduced into the field of private sector training, where Friesen finds the term 'blended learning' used as early as 1999 [3]. The new technology had the potential not only to bridge space, but also to bridge time (through recording), and to individualise learning (by giving the student control over their path through the material, and over the pace of learning). This quartet of time, place, path and pace meant that different educators could value the new technology for different reasons, and have different conceptions of what the new 'blended learning' might mean.

\section{Definitions}

Friesen found that, in the early days of blended learning, the term could mean 'almost any combination of technologies, pedagogies and even job tasks'. Definitions might cover any instructional technology at all, or restrict themselves to web-based technology; they might not mention technology specifically, but instead focus on blending different theoretical approaches [3]. Procter defined blended learning in 2003 as 'the effective combination of different modes of delivery, models of teaching and styles of learning' [4]. According to Chew, Jones and Turner, 'blended learning involves the combination of two fields of concern: education and educational technology' [5]. The broad nature of these definitions meant that critics such as Oliver and Trigwell could attack the concept as ill- 
defined [6]. Eventually different understandings began to converge. An influential early definition was that of Graham, who proposed that 'Blended learning systems combine face-to-face instruction with computer-mediated instruction' [7]. This defines the concept in terms of two modes of course delivery, and defines the blend as some combination of two modes. At the time Graham offered this definition, computer-mediated communication was seen as largely asynchronous and textbased. Now that teleconferencing applications are common, Friesen has suggested the need to redefine 'face-to-face' (F2F) as 'co-present'. For Friesen, "Blended learning" designates the range of possibilities presented by combining Internet and digital media with established classroom forms that require the physical co-presence of teacher and students' [3].

Other theorists and practitioners offer definitions, which are similar to those of Graham and Friesen. For Staker and Horn, blended learning is 'a formal education program in which a student learns at least in part through online delivery of content and instruction with some element of student control over time, place, path, and/or pace and at least in part at a supervised brickand-mortar location away from home' [8]. This definition emphasises that content and instruction must be delivered online, meaning that a traditional face-to-face course in which students are encouraged to use the internet for research does not qualify as blended learning. The phrase 'supervised brick-and-mortar location' means that the 'face-to-face' element need not necessarily consist of traditional classroom contact. Hew and Cheung follow Staker and Horn [9]. Watson and Murin give an expanded version of Staker and Horn's: 'a formal education program in which a student learns at least in part through online learning, with some element of student control over time, place, path, and/or pace; at least in part in a supervised brick-and-mortar location away from home; and the modalities along each student's learning path within a course or subject are connected to provide an integrated learning experience' [10].

For Krasnova, blended learning may be defined as a 'method of teaching that combines the most effective face-to-face teaching techniques and online interactive collaboration, both constituting a system that functions in constant correlation and forms a single whole' [11].

Stacey and Gerbic consider a range of definitions of the term, but at a minimum it involves 'some combination of virtual and physical environments' [12]. For Launer, it is 'the combination of technology supported self or distance study settings and face-to-face settings' [13].

Aside from the broad nature of many early definitions of the concept, Oliver and Trigwell made one more important criticism of blended learning. They argued that by focusing on modes of delivery, theorists were actually focusing more on teaching than on learning. While this critique might not be wholly fair, it does highlight the danger of pursuing technology without adequately considering how it contributes to the learning process [6].

The term 'hybrid learning' appears to be almost synonymous with 'blended learning', however that is defined. In the rest of this paper Friesen's definition, given above, will be adopted, unless otherwise indicated.

\section{Models}

The definitions of blended learning developed by Graham and Friesen, noted above, revolve around bimodal delivery, involving a faceto-face or 'co-present' element, and a computermediated element. However, the ways in which these elements are used for different learning purposes, and the balance between the elements, allow for more than one model to be constructed consistent with these definitions. How may these different models be characterised and classified?

One early typology, suitable for the world of work-related training, was that of Valiathan. This divided blended learning models into three types: those which are skill-driven, aimed at the acquisition of specific knowledge and skills, where the instructor gives feedback and support; those which are attitude-driven, aimed at the development of new attitudes and behaviours, where peer-to-peer interaction and group work are central; and those which are competency-driven, aimed at capturing tacit knowledge, where learners must observe experts at work [14]. This typology has been criticised for its mixed nature, as it is based on both learning objectives and on pedagogical methods [6].

A more influential approach is exemplified by Staker and Horn [8]. They work with a typology of four models, reduced from an original six. The six original models were: (1) the face-toface driven model, in which classroom learning is supplemented with online learning; (2) the rotation model, in which students rotate between working online and other classroom-based modalities; (3) the flex model, in which students 


\section{Теория и методика профессионального образования}

study mainly online according to an individually customised schedule, and face-to-face support is provided by the teacher as needed' (4) the online lab model, in which students supplement their traditional studies by taking an additional online course on-campus; (5) the self-blend model, in which students supplement their traditional studies by taking an additional online course offcampus; (6) the enriched virtual model, in which learning is mainly online with occasional visits to a brick-and-mortar setting for face-to-face tuition. They decided to eliminate model (1) as insufficiently different to (2) and (3), and to merge (4) and (5). This left them with the rotation, flex, self-blend and enriched virtual models. They note different variants of the rotation model, according to whether the student rotates within the classroom, to another room, or off-campus. The most interesting variant of the rotation model is the 'flipped classroom'. Here the student studies online, at a location of their own choosing, in order to receive basic content and instruction. The classroom is used for higher-order tasks such as discussion and evaluation. Thus the order in which the classroom is used for transmission of information, and homework for higher-order assessment of what has been learned, is reversed. The Staker-and-Horn typology is clearly informed by their 'bimodal' definition of blended learning.

Graham suggested classifying blended learning models according to four dimensions, four levels, and three types [7]. His four dimensions were space (face-to-face/virtual), time (synchronous/asynchronous), sensual richness (high, all senses/low, text only) and humanness (high human, no machine/low human, high machine). These are related to the idea of blended learning as defined by bimodal delivery. A second, and entirely different element of classification is introduced by his consideration of level: activity, course, program and institution. Using blended methods for individual learning activities is quite different from blended learning as an institutionwide approach. Finally, Graham introduced three different categories of blend, related to purpose: enabling blends, which focus on access and flexibility; enhancing blends, which seek to supplement traditional pedagogy; and transformative blends, aimed at changing pedagogy, which for Graham meant for example that learners could play a more active role in the construction of their own knowledge. There is a clear implicit hierarchy here, in which transformation is the most worthwhile goal. Graham therefore moved beyond modalities in his typology to consider both scope and pedagogical purpose.

Chew, Jones and Turner not only examined four different models of blended learning but introduced a theoretical basis for critiquing them, by using Vygotsky's and Maslow's insights into learning [5]. The first model they consider is Gill Salmon's structured e-moderation, in which the moderator follows a series of steps to make the student feel welcome in an online environment. Chew et al praise this model as consistent with Maslow's hierarchy of needs. However, it cannot really be considered a model of blended learning in Friesen's sense of the term, and this is probably a consequence of the fact that the authors began with their own rather looser definition of blended learning. The second model is Sun Microsoft Systems' 'learning ecology', documented by Wenger and Ferguson. This model takes the form of a quadrant, with self-directed/guided learning and content/practice axes. Self-directed study of content could mean reading a book or asynchronous online content. Self-directed practice might involve peer-to-peer student discussion. Guided study of content might involve a classroom lecture or video conference. Guided practice might involve mentoring or using a practice laboratory. This model has the virtue that it makes clear that different learning objectives can be delivered using different modes of delivery, a point noted elsewhere by Singh [15]. Chew et al credit the model for its potential to be consistent with the insights of Vygotsky about the Zone of Proximal Development. The learner can construct their own knowledge under expert guidance. Its weakness is that is does not express a clear model for implementation.

Chew et al's third model is Jones' Blended Learning Continuum. While the University of Glamorgan took an institution-wide approach to blended learning, it did not implement it in a uniform way, rather allowing departments to place different modules on a spectrum of e-intensiveness from the minimal (Powerpoint slides) to the wholly-delivered online. Intermediate points on the scale represent access to learning resources, followed by discussion boards, online assessment and interactive material. This model is extremely flexible and recognises that different disciplines may implement blended learning in different ways. Chew et al reject the idea that Jones' Continuum should be cast in percentage terms as Allen, Seaman and Garrett advocate. 
The idea that only a course which is $30-80 \%$ online is blended is an oversimplification, even if it could be agreed what it is that should be measured. However, the model is concerned only with modes of delivery and is theoretically weak [5].

The fourth model is Garrison and Vaughan's Inquiry-Based Framework, which envisages students and teachers as participants in a Community of Inquiry. This term itself is based on Wenger's work on 'communities of practice' [16]. Just as a community of practice consists of a group of practitioners who share a concern and learn how to do it better as they interact, so a Community of Inquiry consists of collaborative learners who construct their own knowledge as they interact. This model shifts the emphasis away from modes of delivery to learning. Technology's role is to enable the three main elements of cognitive presence (information exchange, creating and testing concepts), teaching presence (providing structure and direction) and social presence (allowing group collaboration). Chew et al see the model as being consistent with many of the insights of Vygotsky and Maslow. The process of operationalising such a vision takes time and effort, however [17, 18].

\section{Implications of the models}

The implications of the different models for practitioners of blended learning depend on the intended goals of adopting it, and on how successfully the challenges of implementing it are met. For example, take the 'learning ecology' model discussed above. One of the considerations in developing this model was cost-effectiveness. To someone focused on cost-savings, online selfstudy may seem an attractive mode of delivery. To someone focused on constructivist and collaborative visions of learning, online group discussion may be the crucial feature of course delivery. Either goal may fail to be achieved, for example if software licensing fees are higher than expected, or if online discussion is cumbersome or badly moderated. More than one goal is compatible with the model, and the goal is not guaranteed by the model.

Graham listed six different rationales for adopting blended learning: '(1) pedagogical richness, (2) access to knowledge, (3) social interaction, (4) personal agency, (5) cost-effectiveness, and (6) ease of revision' [7]. Of these, (1), (2) and (5) have been found to be the most popular reasons [7].

Taking access first, Procter [4] and Heinze and Procter [19] suggest that blended learning can improve access to learning for part-time students. Graham [7] lists studies, which show improved access. Few people doubt the potential of blended learning to improve access, and such debate as occurs revolves mainly around the concept of a 'digital divide' in which some sections of society lack the digital means and/or literacy to benefit from widening access. This concern has diminished in importance in developed countries as digital technology has spread.

As for cost-effectiveness, this is a matter of some debate. Graham [7] reports potentially high returns on investment. By contrast Launer denies that blended learning is cheaper, because of the costs of adapting materials, the cost of ICT infrastructure, the need for technical support and the unwisdom of cutting back on teaching support to learners [13]. Graham and Dziuban note that staff savings are the main source of cost savings in introducing blended learning [20].

The biggest debate revolves around pedagogical effectiveness. One advantage of blended learning is that it has the potential to accommodate different learning styles [4]. The question is whether it will deliver that potential. Take the case of the lecture. The role of the lecture in higher education has been called into question for some time now, though it is still a common means of imparting knowledge. It has been fiercely criticised because of its largely unidirectional nature and inefficiency [21]. 'Lecture capture' can allow students to watch lectures at a time and pace of their own choosing, thereby making the process more efficient and accessible to all. However, in the research by Moskal et al, 'lecture capture' is portrayed as a less popular alternative to blended learning [17]. It appears that two of the advantages claimed for online technology (its ability to bridge time and space) are insufficient to make lectures as attractive as more fully blended learning. Take another case, that of group discussion. One advantage sometimes claimed for online discussion is that it allows shy members of a group to participate more readily [9]. However, evidence has also been found that shows some students feel just as inhibited from participating in online discussion [19]. The implication seems to be that simply to move an activity online is not sufficient to secure a pedagogical gain. Other factors, such as style of lecturing or style of moderation, may be just as important.

The overall picture on pedagogical effectiveness has shifted in recent years. As the hype surrounding blended learning grew in its early 


\section{Теория и методика профессионального образования}

years, the balloon was punctured by some research by Thomas Russell. His investigation of the 'No Significant Difference Phenomenon' seemed to demonstrate that learning outcomes were remarkably indifferent to the means of delivery used, for studies conducted over a long period of time [22, 23]. More recently the outcomes of studies, such as those noted by Graham and Dziuban [20] have shifted in favour of blended learning, but it has been suggested that this is explained partly by an alteration in the course content being delivered, so as to make it more suitable for online methods [23]. One explanation for this might be that online assessment methods are geared to what can be automated, something, which is preferred only by novice students [20]. This coincides with anxiety in some countries, such as Britain, that students are becoming less able to cope with the traditional demands of study such as reading a whole book, according to some because of the influence of new technology [24, 25]. However, a metaanalysis by the US Department of Education found that blended learning produces better results than, either face-to-face alone or wholly online methods. The authors were careful to note that they could not be sure that this effect was entirely due to blended learning without the ability to control for other factors such as time spent studying [26]. In general, it is extremely difficult for educational researchers to generate hard experimental evidence about the effectiveness of different methods because there are so many factors to control for, and because of the ethical and practical difficulties in doing so [27].

Given these ambiguities, Krasnova's advice to 'keep an open mind and to focus on the learning experience' seems wise [11]. Her approach to teaching a foreign language using blended learning is pragmatic, using online methods for the roles to which they are best suited. Thus, a grammar module is available for independent study and is assessed by automated tests set at different levels, which the student can choose. Other modules are used as supplements or elective options. The approach broadly matches that advocated by Launer, in which the acquisition of lexis and grammar are seen as more suitable for online methods, while communicative activities, especially speaking and writing, require teacher involvement [13]. On the whole, perceptive language skills (listening and reading) trained online as well as online assessment can both decrease the burden put on the instructor and provide the students with the possibility to follow their individual track.

\section{Conclusion}

The concept of blended learning can not be defined precisely as different scholars put different content into the term, though all of researchers agree that blended learning is an integrated learning experience that is controlled and guided by the instructor whether in the form of face-to-face communication or his virtual presence. Technological innovation is expanding the range of possible solutions that can be brought to bear on teaching and learning. Whether we are primarily interested in creating more effective learning experiences, increasing access and flexibility, or reducing the cost of learning, it is likely that our learning systems will provide a blend of face-to-face and computer mediated experiences. Future learning systems will be differentiated not based on whether they blend but rather by how they blend. This question of how to blend is one of the most important we can consider as we move into the future. Like any design problem this challenge is highly context dependent with a practically infinite number of possible solutions.

\section{References}

1. Barbour M. History of K-12 Online and Blended Instruction Worldwide'. Handbook of Research on K-12 Online and Blended Learning. N.P., ETC Press Publ., 2014, pp. 25-50.

2. Heinze A., Procter C.T. Reflections on the Use of Blended Learning. Available at: usir.salford.ac.uk/1658/1/4247745025H_CP_paper9_5.pdf (accessed 17.03.2016).

3. Friesen M. Report: Defining Blended Learning. Available at: http://blogs.ubc.ca/ nfriesen/2012/09/01/where-does-blended-endvirtual-begin/ (accessed 17.03.2016).

4. Procter C.T. Blended Learning in Practice. Available at: www.ece.salford.ac.uk/proceedings/ papers/cp_03.rtf (accessed 17.03.2016).

5. Chew E., Jones N., Turner D. Critical Review of the Blended Learning Models Based on Maslow's and Vygotsky's Educational Theory' in Hybrid Learning and Education. Berlin, Springer Verlag Publ., 2008, pp. 40-53. DOI: 10.1007/978-3-540-85170-7_4

6. Oliver M., Trigwell K. Can Blended Learning Be Redeemed? E-Learning, 2005, no. 2(1), pp. 17-26. DOI: 10.2304/elea.2005.2.1.17

7. Graham C.R. Blended Learning Systems: Definition, Current Trends, and Future Directions. The Handbook of Blended Learning: Global Perspectives, Local Designs. San Francisco, Pfeiffer Publ., 2006, pp. 3-21.

8. Staker H., Horn M.B. Classifying K-12 
Blended Learning. Available at: http://www. christenseninstitute.org/wp-content/uploads/2013/ 04/Classifying-K-12-blended-learning.pdf $\quad$ (accessed 17.03.2016).

9. Hew K.F., Cheung W.S. Using Blended Learning: Evidence-Based Practices. London, Springer Publ., 2014. 123 p.

10. Watson J., Murin A. A History of K-12 Online and Blended Instruction in the United States. Handbook of Research on K-12 Online and Blended Learning. N.P., ETC Press Publ., 2014, pp. 1-24.

11. Krasnova T. A Paradigm Shift: Blended Learning Integration in Russian Higher Education. Procedia - Social and Behavioral Sciences, 2015, no. 166, pp. 399-403. DOI: 10.1016/j.sbspro.2014.12.543

12. Stacey E., Gerbic P. Success Factors for Blended Learning. Available at: http://www. ascilite.org/conferences/melbourne08/procs/stacey. pdf (accessed 17.03.2016).

13. Launer R. Five Assumptions on Blended Learning: What Is Important to Make Blended Learning a Successful Concept? Hybrid Learning. Berlin, Springer Verlag Publ., 2010, pp. 9-15. DOI: 10.1007/978-3-642-14657-2_2

14. Valiathan P. Blended Learning Models. Available at: http://purnima-valiathan.com/ wpcontent/uploads/2015/09/Blended-LearningModels-2002-ASTD.pdf (accessed 17.03.2016).

15. Singh $\mathrm{H}$. Building Effective Blended Learning Programs. Educational Technology, 2006, no. 43(6), pp. 51-54.

16. Wenger E. Communities of Practice: a Brief Introduction. Available at: http://wengertrayner.com/theory/ (accessed 17.03.2016).

17. Moskal P., Dziuban C., Hartman J. Blended Learning: A Dangerous Idea? Internet and Higher Education, 2013, no. 18, pp. 15-23. DOI: 10.1016/j.iheduc.2012.12.001

18. Vaughan N.D. A Blended Community of Inquiry: Linking student and course redesign. Internet and Higher Education, 2009, no. 13, pp. 60-65. DOI: 10.1016/j.iheduc.2009.10.007

19. Heinze A., Procter C.T. Reflections on the Use of Blended Learning. Available at: usir.salford.ac.uk/1658/1/4247745025H_CP_paper9 5.pdf (accessed 17.03.2016).

20. Graham C.R., Dziuban C.D. Blended Learning Environments. Handbook of Research on Educational Communications and Technology. Mahwah, Lawrence Earlbaum Publ., 2008, pp. 269-276.

21. Ellis C. You Can't Do That in a Classroom!: How Distributed Learning Can Assist in the Widespread Adoption of Hybrid Learning Strategies. Hybrid Learning and Education: Proceedings of First International Conference. Berlin, Springer Verlag Publ., 2008, pp. 1-16. DOI: 10.1007/978-3-540-85170-7_1

22. Ramage T.R. The "No Significant Difference" Phenomenon: A Literature Review. Available at: http://spark.parkland.edu/ramage_ pubs/1 (accessed 17.03.2016).

23. WCET (WICHE Cooperative for Education Technologies). The No Significant Difference Phenomenon. Available at: http:// www.nosignificantdifference.org/ (accessed 17.03.2016).

24. Pells R. University Students are Struggling to Read Entire Books. Available at: http:// www.independent.co.uk/news/education/university -students-are-struggling-to-read-entire-booksa6986361.html (accessed 17.03.2016).

25. Furedi F. We Must Instil a Love of Reading in Students. Available at: https://www. timeshighereducation.com/opinion/we-mustinstil-a-love-of-reading-in-students (accessed 17.03.2016).

26. Means B., Toyama Y., Murphy R., Bakia M., Jones K. Evaluation of EvidenceBased Practices in Online Learning: A MetaAnalysis and Review of Online Learning Studies. Washington, US Department of Education Publ., $2010.94 \mathrm{p}$.

27. Lowes S. A Brief Look at the Methodologies Used in the Research on Online Teaching and Learning. Handbook of Research on K-12 Online and Blended Learning. N.P., ETC Press Publ., 2014, pp. 83-106.

Received 20 March 2016 


\title{
СМЕШАННОЕ ОБУЧЕНИЕ: ОПРЕДЕЛЕНИЕ, МОДЕЛИ, ИСПОЛЬЗОВАНИЕ В СИСТЕМЕ ВЫСШЕГО ОБРАЗОВАНИЯ
}

\author{
А. Брайан, К.Н. Волченкова \\ Южно-Уральский государственный университет, г. Челябинск
}

\begin{abstract}
Проект 5-100, реализуемый Министерством Образования Российской Федерации, направлен на интернационализацию ведущих российских университетов на мировом образовательном рынке. В 2015 году Южно-Уральский государственный университет (ЮУрГУ) стал частью этого проекта, что, наряду с возможностью кардинальных преобразований привело к необходимости выполнения ряда показателей, которые нужно достичь для того, чтобы подтвердить эффективность вводимых мер. Одним из проектов в Дорожной Карте ЮУрГУ стал проект по внедрению системы углубленной языковой подготовки студентов бакалавриата. Реализация данного проекта невозможна без внедрения новых технологий обучения, одной из которых является технология смешанного обучения.

В статье дается определение технологии смешанного обучения, анализируется ее потенциальные возможности в качестве дидактического средства при переходе с традиционной модели обучения на интегрированную модель с привлечением электронных средств и ресурсов. Рассматриваются существующие модели смешанного обучения, обсуждаются способы их адаптации под условия российской вузовской системы подготовки на примере учебной дисциплины «Иностранный язык». Результаты анализа технологии смешанного обучения могут быть использованы при разработке интегрированной модели обучения в системе высшего образования.
\end{abstract}

Ключевые слова: Проект 5-100, технология, смешанное обучение, модель, интеграция, языковая подготовка.

Брайан Антоний, доцент кафедры русского языка как иностранного языка, Институт лингвистики и международных коммуникаций, Южно-Уральский государственный университет, г. Челябинск, braiana@susu.ru.

Волченкова Ксения Николаевна, доцент кафедры русского языка как иностранного языка, Институт лингвистики и международных коммуникаций, Южно-Уральский государственный университет, г. Челябинск, volchenkovakn@susu.ru.

Поступила в редакцию 20 марта 2016 2.

\section{ОБРАЗЕЦ ЦИТИРОВАНИЯ}

Bryan, A. Blended learning: definition, models, implications for higher education / A. Bryan, K.N. Volchenkova // Вестник ЮУрГУ. Серия «Образование. Педагогические науки». - 2016. - Т. 8, № 2. - С. 24-30. DOI: $10.14529 /$ ped160204

\section{FOR CITATION}

Bryan A., Volchenkova K.N. Blended Learning: Definition, Models, Implications for Higher Education. Bulletin of the South Ural State University. Ser. Education. Educational Sciences. 2016, vol. 8, no. 2, pp. 24-30. DOI: 10.14529/ped160204 